F. Reprod. Fert. (1967) 13, 511-516

\title{
THE INFLUENCE OF EMBRYONIC TISSUE HOMOGENATE INFUSED INTO THE UTERUS, ON THE LIFE-SPAN OF THE CORPUS LUTEUM IN THE SHEEP
}

\author{
L. E. A. ROWSON AND R. M. MOOR \\ A.R.C. Unit of Reproductive Physiology and Biochemistry,* University of Cambridge
}

(Received 12th October 1966)

\begin{abstract}
Summary. Following the daily intra-uterine infusion of a homogenate prepared from frozen and thawed tissue of 14- or 15-day sheep embryos the length of the oestrous cycle was significantly prolonged. A single intra-uterine infusion, however, had only a slight effect on oestrous cycle length.

The substance derived from the embryonic tissue, which presumably must be of a chemical nature, probably acts on the endometrium in an 'anti-luteolytic' manner, that is by counteracting the action of the endometrium which otherwise would have resulted in the regression of the corpus luteum.

Unlike homogenate prepared from 14- or 15-day sheep embryos similar material obtained from 25-day sheep embryos did not increase cycle length. This indicates that the effect is dependent on the stage of development of the embryo in relation to the uterus.

Homogenate prepared from 14-day pig embryos infused into sheep uteri was unable to maintain the corpus luteum, which suggests that the embryonic factor may be species-specific. Repeated intra-uterine infusions of control material consisting of frozen and thawed saline, serum or serum plus white blood cells had no effect on cycle length. Transfer into the sheep uterus of a whole but heat-inactivated 12-14days sheep embryo had no effect on the cycle length.
\end{abstract}

\section{INTRODUCTION}

It has been clearly demonstrated that the presence of an embryo within the sheep uterus by the 12th day of the oestrous cycle is essential if the cyclical corpus luteum is to become established as the corpus luteum of pregnancy (Moor \& Rowson, 1966a, b). The mechanism by which the embryo prevents luteal regression is unknown, but preliminary experiments involving the intramuscular injection of embryonic tissue homogenate, starting on the 12th day of cycle, did not prolong luteal function. It, therefore, became necessary to

\footnotetext{
* Postal address: Animal Research Station, 307 Huntingdon Road, Cambridge.
} 
devise a method whereby repeated infusions of embryonic tissue homogenate or other materials could be made directly into the uterus itself.

There are a number of possible mechanisms by means of which the embryo might exert its luteotrophic action and it is the purpose of these experiments to investigate some of these.

\section{MATERIALS AND METHODS}

A total of fifty-seven recipient sheep comprising fifty-three Welsh, two Suffolk and two Blackface ewes was used in these experiments. Donor animals comprised 108 ewes and four gilts. Oestrus was detected by the use of either a raddled vasectomized, or fertile ram according to the experimental group.

Because of the failure of intramuscular injection of embryonic homogenate to influence luteal function it was considered necessary to introduce the infused material directly into the uterus so as to facilitate any direct action which material of that kind might exert on the uterus or ovaries. This was achieved by inserting and ligating a fine polythene tube (external diameter $2 \mathrm{~mm}$ ), attached to a special collar, into the tip of the uterine horn of the recipient ewes on the side adjacent to the ovary containing the corpus luteum. The polythene tube was passed through the flank and then through the wool to the lumbar spinal region. During the process of anchoring the tube within the uterus care was taken to avoid interference with blood vessels. To minimize damage to the abdominal wall a trochar and cannula $(3 \mathrm{~mm}$ internal bore) was inserted through the wall first and the polythene tubing threaded through this. After removal of the cannula the tubing was anchored by two or three stitches on its path through the wool to the lumbar spinal region.

All corpora lutea were marked with animal charcoal during the operation, which was performed under Pentobarbitone sodium anaesthesia, supplemented by cyclopropane and oxygen. The polythene tubes were inserted into the recipient ewes on the 10th to 12th day of the cycle, oestrus having been previously detected by a raddled vasectomized ram and the onset recorded as Day 0. All experimental treatments commenced on Day 12.

The fifty-seven recipient ewes were divided into the following six groups according to planned treatment (number of recipients in parentheses):

(1) Ewes to receive a single infusion of frozen and thawed 14- or 15-day sheep embryo homogenate (twenty-five).

(2) Ewes to receive repeated daily infusions of frozen and thawed 14- or 15-day sheep embryo homogenate (nine).

(3) Ewes to receive repeated daily infusions of frozen and thawed 25-day sheep embryo homogenate (six).

(4) Ewes to receive repeated daily infusions of frozen and thawed 14-day pig embryo homogenate (five).

(5) Ewes to receive repeated daily infusions of 'control material' comprising either frozen and thawed saline or serum or serum plus white blood cells (six).

(6) Ewes to be laparotomized and to receive a whole 12- or 14-day embryo which, however, had been previously heat-treated by immersing in a water- 
bath at $100^{\circ} \mathrm{C}$ for $5 \mathrm{~min}$. The heat-treated embryos were transferred into the uteri so as to discover whether they would have the same effect on luteal function as intact embryos (five).

The embryonic material used in Groups 1, 2, 4 and 6 was obtained from the uteri of 104 donor ewes and four donor pigs on the 12th to 15th day of pregnancy. The 104 donor ewes which had been previously superovulated by gonadotrophin treatment ( 800 to $1000 \mathrm{i}$.u. of PMS) so as to provide as many embryos as possible, were laparotomized, their uteri flushed with physiological saline and the recovered embryos stored at $-20^{\circ} \mathrm{C}$ until required. The four donor gilts (all of which were 14 days pregnant) were laparotomized and a glass cannula inserted into the tip of each uterine horn. The embryos were flushed out with normal saline and stored at $-20^{\circ} \mathrm{C}$. Before infusion, the frozen sheep and pig embryos were thawed and their tissues broken up into milky homogenate by repeatedly drawing the material in and out of the syringe.

The material infused into Group 3 consisted of the contents of the uteri from 25-day pregnant donor ewes, including embryo, membranes and foetal fluids: all that material was disintegrated in a percussion mortar pre-cooled to $-79^{\circ} \mathrm{C}$ in dry ice. This procedure was necessary because of the more elastic nature of the foetal membranes at this stage of pregnancy. Following disintegration the suspension was stored at $-20^{\circ} \mathrm{C}$. The embryonic contents of each 25-day pregnant uterus provided sufficient material for approximately ten daily infusions.

All intra-uterine infusions were carried out by puncturing the polythene tube over the lumbar region with a fine needle (No. 15) after previously sterilizing the outside of the tubing with alcohol. Penicillin, 1000 units $/ \mathrm{ml}$, was added to the embryo homogenate and also to the 'control material' Group 5, before infusion.

Each daily infusion of embryo homogenate in Groups 1, 2 and 4 contained the equivalent of between one and two embryos. Because of the large number of embryos required to carry out the repeated infusion experiments (Group 2, 3 and 4) the number of experimental animals was, of necessity, small in these groups.

Group 6 consisted of 12-day recipient ewes to which heat-treated embryos were transferred using the technique described by Rowson \& Moor (1966) for live embryos at this stage.

Any ewe which had not returned to oestrus by Day 25 was autopsied. The corpora lutea and uteri of these animals were examined macroscopically and were then fixed for histology. A 20-ml aliquot of blood was withdrawn from the vein draining the ovary containing the corpus luteum in one of these sheep just before autopsy. The concentration of progesterone in this sample was estimated by the method of Short (1958).

\section{RESULTS}

A single intra-uterine infusion of a tissue homogenate prepared from 14- or 15-day embryos resulted in an extension of the oestrous cycle (i.e. $>19$ days) 
in nine out of the twenty-six ewes in Group 1 (Table 1). The overall mean cycle length of the ewes in this group was extended to $19.4 \pm 0.84$ days as compared with the normal cycle length of $16 \cdot 6 \pm 0 \cdot 1$ days. However, two animals had post-treatment cycles of 29 and 33 days respectively, possibly indicating two normal oestrous cycles, the intervening ovulation having occurred without overt oestrus. Eliminating these two animals, the mean length of the oestrous cycles in Group 1 ewes was 18.5 days, a figure not significantly different from the normal cycle length.

TABLE 1

THE EFFECT OF INTRA-UTERINE INFUSIONS OF EMBRYONIC MATERIAL ON THE LENGTH OF THE OESTROUS CYCLE OF THE EWE

\begin{tabular}{|c|c|c|c|c|c|c|}
\hline \multirow[t]{2}{*}{ Group } & \multirow[t]{2}{*}{ Treatment } & \multirow{2}{*}{$\begin{array}{l}\text { No. of } \\
\text { recipient } \\
\text { ewes }\end{array}$} & \multicolumn{3}{|c|}{$\begin{array}{l}\text { No. of recipients returning to oestrus } \\
\text { with normal or standard cycles }\end{array}$} & \multirow{2}{*}{$\begin{array}{c}\text { Mean cycle } \\
\text { length }+ \text { S.E. } \\
\quad(\text { days })\end{array}$} \\
\hline & & & $\begin{array}{c}\text { Normal cycles } \\
(<19 \text { days })\end{array}$ & $\mid \begin{array}{r}\text { Exten } \\
(19 \text { to } 24 \text { day }\end{array}$ & 5 days) & \\
\hline 1 & $\begin{array}{l}\text { A single intra-uterine } \\
\text { infusion of } 14-\text { or } 15- \\
\text { day sheep embryo } \\
\text { suspension }\end{array}$ & 26 & 17 & 7 & 2 & $19 \cdot 4 \pm 0 \cdot 84$ \\
\hline 2 & $\begin{array}{l}\text { Repeated daily intra- } \\
\text { uterine infusion of 14- } \\
\text { or 15-day sheep } \\
\text { embryo suspension }\end{array}$ & 9 & 1 & 4 & 4 & $>22 \cdot 4$ \\
\hline 3 & $\begin{array}{l}\text { Repeated daily intra- } \\
\text { uterine infusions of } \\
\text { 25-day sheep embryo } \\
\text { suspension }\end{array}$ & 6 & 6 & 0 & 0 & $17 \cdot 0 \pm 0 \cdot 36$ \\
\hline 4 & $\begin{array}{l}\text { Repeated daily intra- } \\
\text { uterine infusion of } \\
\text { 14-day pig embryo } \\
\text { suspension }\end{array}$ & 5 & 4 & 1 & 0 & $17 \cdot 8 \pm 0.37$ \\
\hline 5 & $\begin{array}{l}\text { Repeated daily intra- } \\
\text { uterine infusion of } \\
\text { control material }\end{array}$ & 6 & 6 & 0 & 0 & $17 \cdot 3 \pm 0.33$ \\
\hline 6 & $\begin{array}{l}\text { Transfer of inert } \\
\text { heat-treated embryos }\end{array}$ & 5 & 5 & 0 & 0 & $16 \cdot 8 \pm 0 \cdot 44$ \\
\hline
\end{tabular}

By contrast eight of the nine ewes in Group 2 which received repeated daily intra-uterine infusions of 14- or 15-day sheep embryo homogenate showed a significant extension of cycle length after treatment. The mean length of the oestrous cycle in this group was over 22.4 days. Four of the nine recipients had not shown oestrus by Day 25 and at autopsy three of these recipients were found to have fully functional marked corpora lutea. The progesterone level in the ovarian venous blood of one of these three was estimated and was found to be $145 \mu \mathrm{g}$ progesterone $/ 100 \mathrm{ml}$ of plasma. In the fourth animal the marked corpus luteum was regressing and a large follicle was present, indicating that the ewe was about to come into oestrus. The uteri of these four sheep were examined histologically and were found to be apparently normal except that 
some embryonic debris and white cells were found in the uterine lumen of two of the animals.

The daily infusion of homogenates of 25-day sheep embryos (Group 3), 14-day pig embryos (Group 4), or of control material (Group 5) or the heattreated embryos (Group 6) did not significantly extend the oestrous cycles of any of the recipient ewes; the mean length for each of these groups being $17 \cdot 0 \pm 0 \cdot 36,17 \cdot 8 \pm 0 \cdot 37,17 \cdot 3 \pm 0 \cdot 33$ and $16 \cdot 8 \pm 0.44$ days.

\section{DISGUSSION}

The results of these experiments demonstrate that homogenates prepared from frozen 14- or 15-day sheep embryos prevent luteal regression when introduced daily into the uteri of non-pregnant ewes from the 12th day after oestrus. However, similar suspensions prepared from 25-day sheep conceptuses, from 14-day pig embryos or from serum and white cells or saline alone and administered in an exactly comparable manner to the above, had no significant effect on the normal cyclical life-span of the corpus luteum. These findings indicate that the active principle in the early sheep embryos is retained when stored at $-20^{\circ} \mathrm{C}$ for long periods and it is thus probably 'chemical' in nature. Furthermore, it would seem that factor may be species-specific and its action is possibly also related to the stage of development of both the embryo and the uterus.

It is not clear what effect the freezing, thawing and homogenizing procedure has on the sheep embryonic tissue since D. R. S. Kirby (personal communication) has recently reported that mouse trophoblast cells will often withstand and even grow after repeated freezing and thawing. Although no histological or other evidence of growth or survival of the infused embryonic material has been obtained in the present work, it is not yet possible to state with certainty that our infused trophoblast cells were entirely non-viable. It is perhaps significant to point out, however, that repeated daily administrations of embryonic homogenate were necessary to obtain consistent maintenance of the corpora lutea.

The mode of action of the embryo or its homogenate remains to be explored further. It may be that it acts locally upon the endometrium, either by preventing the release of a 'luteolysin' or by counteracting the latter. It has been shown by Moor \& Rowson (1966c) that in order to exert its normal luteotrophic effect the embryo, or its secretions, must be in a position to exert a direct effect on the endometrium of the horn adjacent to the ovary containing the corpus luteum. Any complete barrier to the continuity of the uterine lumen, such as a ligature placed between the gravid and non-gravid horn, will result in failure of pregnancy if the corpus luteum is in the ovary of the non-pregnant side. The fact that the pregnancy can continue normally if the uterine horn of the non-gravid side is removed would suggest that the effect of the embryo depends on counteracting the 'luteolytic' effect of the endometrium. Moreover, the observation that a single infusion of an embryonic tissue homogenate (Group 1) is much less effective than a repeated infusion (Group 2) indicates that in order to exert its normal effect a continuous secretion of the anti-luteolytic substance is required from the embryo. 
The fact that a tissue-homogenate prepared from 14- and 15-day embryos can prolong the oestrous cycle while that from a 25-day sheep embryo (Group 3) is ineffective, may be taken as an indication that the stage of development of the embryo in relation to that of the uterus is an important factor in determining the extent of an anti-luteolytic effect. It may well be that the same factor plays a role in the necessity for synchronization of cycles between donor and recipient, which is an important pre-requisite for successful egg transfer.

The fact that the cycle length is not prolonged in sheep after repeated infusions of homogenate from pig embryos of an age when they were likely to exert their effect in the pig (Group 4) indicates that the anti-luteotrophic substance may not be identical for all species. The injection of such embryo homogenates also provided an additional control on the possible effect on cycle length of the intra-uterine infusion of cellular homogenate.

Similarly, repeated control infusions of saline, serum or serum plus white blood cells failed to influence cycle length.

Nalbandov \& St Clair (1958) have suggested that the physical presence of an embryo within the uterus might act via nervous pathways and stimulate luteal maintenance through the central nervous system. Our experiments have shown, however, that the physical presence within the uterus of an embryo, which had been killed by heating, is ineffective in prolonging the length of cycle in the sheep, whereas suspensions of frozen embryonic homogenates do prolong luteal function. We, therefore, suggest that at this stage of pregnancy distension alone is unlikely to play a major role in preventing luteal regression in the sheep.

\section{ACKNOWLEDGMENTS}

We are indebted to the staff at the Unit and particularly to $\mathrm{Mr} \mathrm{H}$. Strange for his help throughout the experiments. We would like to thank Dr T. R. R. Mann for his continuous encouragement and for reading and discussing the manuscript with us.

\section{REFERENCES}

Moor, R. M. \& Rowson, L. E. A. (1966a) The corpus luteum of the sheep: effect of removal of the embryos on luteal function. F. Endocr. 34, 497.

Moor, R. M. \& Rowson, L. E. A. (1966b) The corpus luteum of the sheep: functional relationship between the embryo and corpus luteum. F. Endocr. 34, 233.

Moor, R. M. \& Rowson, L. E. A. (1966c) Local uterine mechanisms affecting luteal function in the sheep. F. Reprod. Fert. 11, 307.

Nalbandov, A. V. \& St Clair, L. E. (1958) Relation of the nervous system to implantation. Reproduction and Infertility, IIIrd Symposium, pp. 83-87. Ed. F. X. Gassner. Pergamon Press, New York.

Rowson, L. E. A. \& Moor, R. M. (1966) Embryo transfer in the sheep: the significance of synchronizing oestrus in the donor and recipient animal. F. Reprod. Fert. 11, 207.

ShORT, R. V. (1958) Progesterone in blood. I. The chemical determination of progesterone in peripheral blood. $\mathcal{F}$. Endocr. 16, 415. 